\title{
Cocaine Increases Natural Killer Cell Activity
}

\author{
Craig Van Dyke, Alan Stesin, Reese Jones, Anan Chuntharapai, and William Seaman \\ Psychiatry and Medical Services, San Francisco Veterans Administration Medical Center, \\ and University of California, San Francisco, California 94121
}

\begin{abstract}
The administration of epinephrine to humans increases natural killer (NK) cell activity and numbers. If endogenous catecholamines regulate NK cells, then their activity should be increased by cocaine, an agent that potentiates endogenous catecholamines. We investigated the in vivo effect of cocaine on NK cell activity and on the distribution of lymphocyte subsets, including NK cells. Intravenous cocaine $(0.6 \mathrm{mg} / \mathrm{kg})$ produced a three- to fourfold increase in NK cell activity in peripheral blood. The increase was accompanied by a marked and selective increase in circulating $N K$ cells, as identified by the $F_{c}$ receptor (Leu-11). Normal saline and benzoylecgonine, a major metabolite of cocaine, had little effect on NK cell activity or on levels of Leu-11+ cells. Other lymphocyte subpopulations were not increased by cocaine. The time course of the alterations in NK cell numbers and activity paralleled plasma levels of cocaine. In vitro cocaine did not increase NK cell activity. Our results indicate that cocaine selectively alters the activity and distribution of the NK lymphocyte subset. Because cocaine increases the activity of endogenous catecholamines, these findings suggest that human NK cells are selectively regulated by the sympathetic nervous system.
\end{abstract}

\section{Introduction}

Natural killer (NK) ${ }^{1}$ cells are large granular lymphocytes that spontaneously lyse certain tumor cells as well as some normal cells. NK cells may function in host defense against certain malignancies and viral infections (1-9), but accumulating evidence suggests that their primary role is to regulate antibody production (10-18). NK cell activity can be increased in vitro by interferon or by interleukin 2 (19-21). In humans NK cell activity is increased by exercise $(22,23)$ or by the administration of adrenergic agents (24-26), although adrenergic agents in vitro reduce NK cell activity by increasing intracellular cyclic AMP (27). Thus, NK cell activity in humans may be partially regulated by the adrenergic nervous system.

Address correspondence to Dr. Van Dyke, Veterans Administration Medical Center, 4150 Clement Street, San Francisco, CA 94121. Received for publication 26 November 1985.

1. Abbreviations used in this paper: ANOVA, analysis of variance; $\mathrm{BE}$, benzoylecgonine; NK, natural killer; PBMC, peripheral blood mononuclear cells.

The Journal of Clinical Investigation, Inc.

Volume 77, April 1986, 1387-1390
Cocaine is a central nervous system stimulant that has become a major drug of abuse. It is still used in clinical medicine as a local anesthetic and vasoconstrictor. Cocaine's sympathomimetic activity involves at least two mechanisms: $(a)$ the release of endogenous catecholamines from the adrenal medulla, a response mediated by the central nervous system, and $(b)$ inhibition of norepinephrine reuptake by the sympathetic nervous system $(28,29)$. Because cocaine increases the activity of endogenous catecholamines, we examined its effect on NK cell activity in humans. We also examined the effects of normal saline and benzoylecgonine (BE), a major metabolite of cocaine that has no reported biological activity.

\section{Methods}

Eight healthy subjects (six males, two females), age 21-33 yr, participated after their informed consent under a protocol approved by the University of California, San Francisco Committee on Human Research. All had used cocaine occasionally but were not habitual users. They were unaware of the choice of treatment but knew that they would receive either cocaine hydrochloride $(0.6 \mathrm{mg} / \mathrm{kg}$ as a $10-\mathrm{mg} / \mathrm{ml}$ solution $), \mathrm{BE}$ tetrahydrate $(0.4$ $\mathrm{mg} / \mathrm{kg}$ as a $10-\mathrm{mg} / \mathrm{ml}$ solution, an amount calculated to provide peak plasma levels similar to those derived from $0.6 \mathrm{mg} / \mathrm{kg}$ of cocaine), or normal saline $(3 \mathrm{ml})$. Most subjects received, on separate days, both cocaine and BE. The total dose of cocaine ranged from 32 to $59 \mathrm{mg}$ and the dose of $B E$ ranged from 23 to $30 \mathrm{mg}$. In the initial experiments (four cocaine, three BE), NK cell activity was measured before and $20 \mathrm{~min}$ after a 1-min intravenous drug infusion. In eight subsequent experiments (three each with cocaine and BE, two with saline) blood was obtained before drug administration and 5, 20,60,120,180,240, and $300 \mathrm{~min}$ thereafter to measure: $(a)$ NK cell activity, $(b)$ peripheral blood mononuclear cell subsets as determined by fluorescence analysis, and $(c)$ plasma levels of cocaine.

Cocaine hydrochloride (Mallinckrodt, Inc., St. Louis, MO) and BE tetrahydrate dissolved in preservative-free normal saline were injected by infusion pump into a flowing intravenous catheter in a large forearm vein. Blood samples for immune measures and drug levels were obtained from an intravenous catheter in the opposite arm. Blood samples for assay of cocaine plasma levels were drawn into heparinized tubes containing $0.2 \mathrm{ml}$ of saturated $\mathrm{NaF}$ and placed on ice to prevent both spontaneous and enzymatic hydrolysis of cocaine by plasma esterases. The plasma was immediately separated and frozen at $-10^{\circ} \mathrm{C}$ until analysis by gas-chromatographic methods (30).

BE was prepared by hydrolysis of cocaine base in boiling distilled water for $12 \mathrm{~h}$ followed by recrystallization twice from water. Purity was checked by melting point determinations and thin-layer chromatography. By these indices our material was identical with authentic samples from the National Institute on Drug Abuse.

Peripheral blood mononuclear cells (PBMC) were obtained by density centrifugation and were tested against $\mathrm{K} 562$ target cells in a 4-h ${ }^{51} \mathrm{Cr}$ release assay (31). Triplicate samples were tested at PBMC/target cell ratios of 40:1, 20:1, 10:1, and 5:1. For studies of NK cell activity over time, cytotoxicity was quantified by determining the number of lytic 
units in a fixed number of effector cells (32). One lytic unit was defined as the number of PBMC required to lyse $2.5 \times 10^{3} \mathrm{~K} 562$ target cells ( $25 \%$ lysis), a point always on the linear portion of the cytotoxicity curve. To compare changes in NK cell activity to changes in the number of Leu- $11+$ cells $/ \mathrm{mm}^{3}$ of blood, we determined the number of lytic units within the lymphocytes in 1 cubic millimeter of blood.

For fluorescence analysis, $10^{5}$ PBMC were suspended in $50 \mu \mathrm{l}$ of Hanks' balanced salt solution (HBSS) with $1 \%$ fetal bovine serum plus $0.02 \mathrm{~g} / \mathrm{dl}$ sodium azide. The cells were incubated on ice for $30 \mathrm{~min}$ with $1 \mu \mathrm{g}$ of monoclonal antibody conjugated with fluorescein isothiocyonate. The cells were then washed twice with HBSS and resuspended in $300 \mu \mathrm{l}$ of HBSS for analysis by use of a fluorescence-activated cell sorter (FACS II; Becton-Dickinson \& Co., Oxnard, CA). A minimum of 2,000 cells were analyzed for each antibody. The monoclonal antibodies recognized Leu-11, on NK cells; Leu-3a and Leu-3b, on "helper" T cells; Leu-2a, on "suppressor/cytotoxic" $\mathrm{T}$ cells (all from Becton-Dickinson \& Co.); B-1, on B cells (Coulter Electronics, Inc., Hialeah, FL); and OKM-5, on monocytes (Ortho Diagnostic Systems, Inc., Raritan, NJ). Fluorescence analysis allowed determination of the percent of each cell type within the PBMC. To determine the number of circulating fluorescent cells/ $\mathrm{mm}^{3}$, the number of circulating white blood cells and the percent of lymphocytes were determined by size and staining of blood cells using an H-6000 cell analyzer (Technicon Instruments Corp., Tarrytown, NY). From this, the number of circulating lymphocytes and the number of circulating lymphocyte subsets could be derived.

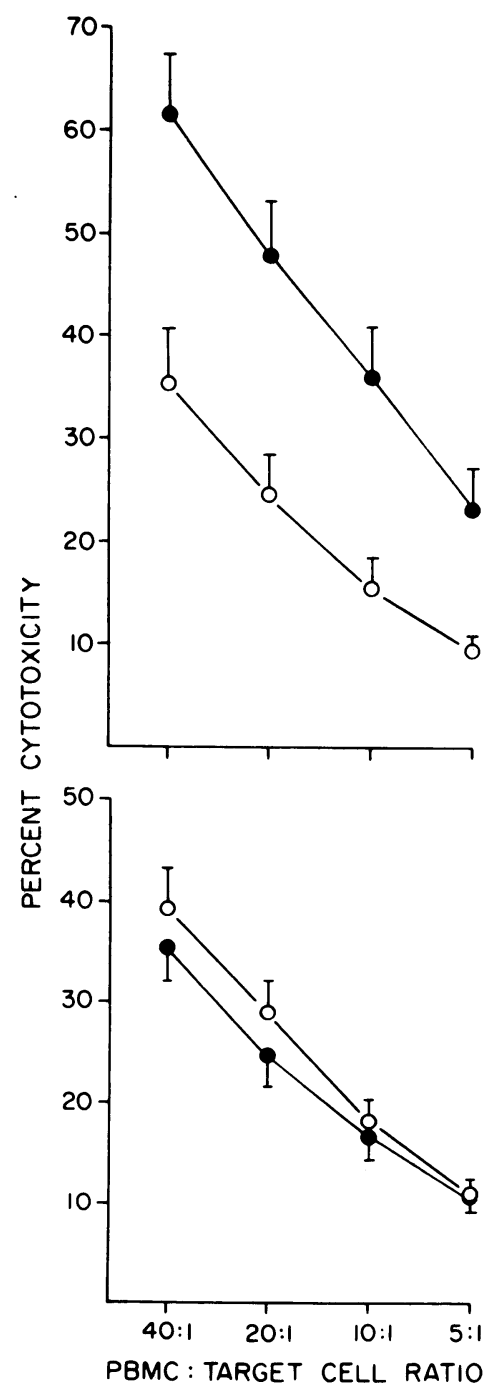

\section{Results}

20 min after administration, cocaine caused an almost fourfold increase in NK cell activity (analysis of variance [ANOVA], $P$ $\leq 0.005$ ) (Fig. 1), i.e., the number of PBMC that were required to kill a fixed number of target cells fell to one-fourth of predrug values $(32,33)$. BE had no effect 20 min after administration (Fig. 1). After cocaine, NK cell activity increased rapidly within $5 \mathrm{~min}$, remained elevated at $20 \mathrm{~min}$, and gradually declined to predrug levels by 80 min (Fig. 2). Changes in NK cell activity were temporally related to changes in plasma levels of cocaine (Fig. 2). After BE, NK cell activity was slightly elevated at 5 min but not thereafter (Fig. 2). Saline injections caused no increase in NK cell activity (not shown).

To determine if the rise in NK cell activity was due to an increase in circulating NK cells or to an increase in their lytic activity, NK cells were quantified by staining PBMC with antibody to Leu-11. Leu-11 is an immunoglobulin receptor $\left(F_{c}\right.$ receptor, cluster designation 16) found on all NK cells but on few, if any, T cells, B cells, or monocytes. After cocaine injection, levels of circulating Leu- $11+$ cells increased $>270 \%$ within 5 min and gradually returned to baseline levels after $1 \mathrm{~h}$ (ANOVA, $P \leq 0.01$ ) (Fig. 2). BE produced a much smaller and more tran-
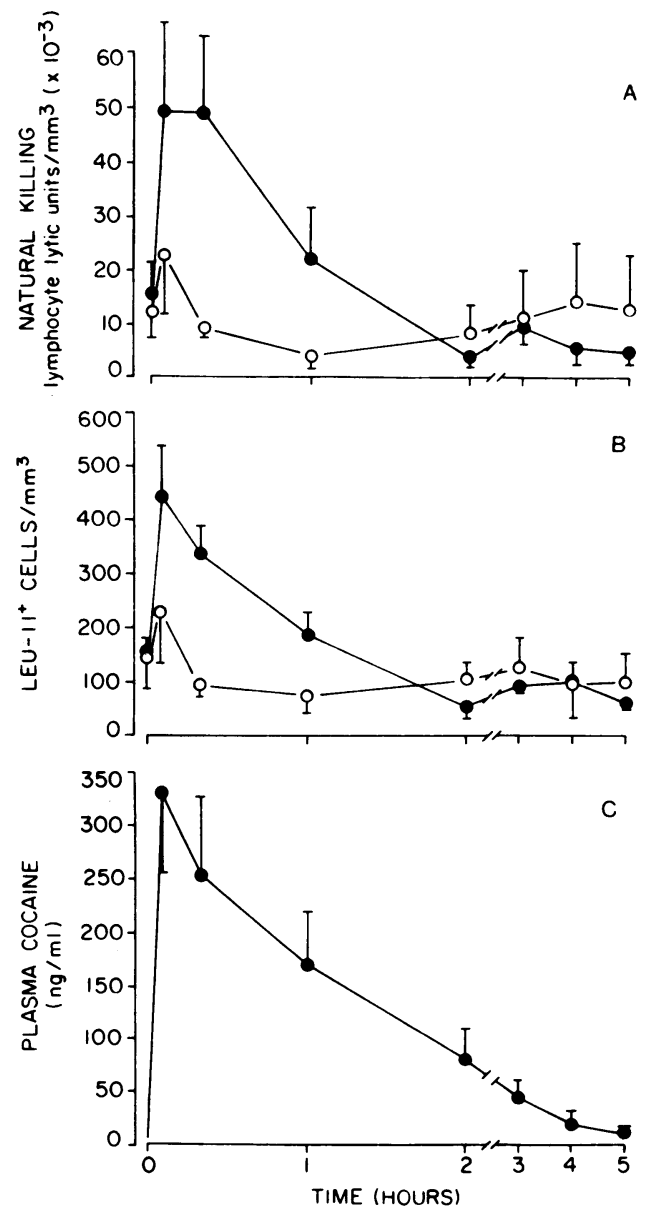

Figure 2. Effects over time of cocaine (๑) or benzoylecgonine (O) on NK cell activity $(A)$, number of circulating Leu-11+ cells $(B)$, and cocaine plasma levels $(C)$. NK cell activity is presented in lytic units within the total lymphocyte population. Each value is the mean \pm SEM for three individuals. 
sient increase in Leu-11+ cells (Fig. 2). After saline injection there was no increase in Leu-11+ cells (not shown). The increase in NK cell levels was selective, since other lymphocyte subsets and monocytes were not significantly altered by cocaine when compared with BE and saline, as assessed by staining for Leu-3 ("helper" T cells), Leu-2 ("suppressor/cytotoxic" T cells), B-1 (B cells), and OKM-5 (monocytes) (not shown).

\section{Discussion}

These findings show that cocaine rapidly increases NK cell activity in humans. Quantification of lymphocyte subsets indicates that much of the rise in NK cell activity after cocaine may be due to an increase in the number of circulating NK cells as identified by Leu-11. In addition to changes in numbers of Leu$11+$ cells, there may be increased lytic activity per cell because the rise in killing (average, 380\%) was greater than the rise in Leu- $11+$ cells (270\%). Also, killing remained elevated between 5 and 20 min, while the number of Leu- $11+$ cells fell. However, since not all Leu-11+ cells mediate natural killing, only a subset of cytotoxic Leu-11+ cells may have increased to the same extent as NK cell activity, without an increase in cytotoxicity by individual cells. Our findings do not establish whether the increase in Leu-11+ cells in blood results from activation of Leu-11cells or from recruitment of Leu-11+ cells from other sites.

The substantial in vivo effects of cocaine contrast sharply with the lack of effect of cocaine on NK cell activity in vitro. We found only one other report examining the effects of cocaine on NK cell activity (34). In vitro cocaine had no effect on NK cell activity at concentrations below $0.5 \mathrm{mg} / \mathrm{ml}$. Between 0.5 and $100 \mathrm{mg} / \mathrm{ml}$ there was a dose-dependent decrease in NK cell activity. These cocaine concentrations are at least 1,000 times greater than those observed in our study. We also conducted in vitro experiments and determined that cocaine had no effects on NK cell activity in concentrations similar to those observed in humans (not shown). Other local anesthetics, lidocaine and procaine, decrease NK cell activity in vitro when concentrations are $>10^{-3} \mathrm{M}(35)$.

The increased NK cell activity after cocaine in vivo is not likely due to the metabolism of cocaine, because $\mathrm{BE}$, a major cocaine metabolite, had relatively little effect on NK cell numbers or activity. BE produced none of the typical mood, symptom, and cardiovascular system changes that followed cocaine, which is consistent with BE lacking sympathomimetic activity. The absence of NK cell stimulation after BE or saline administration indicates that increased NK cell activity after cocaine is not simply a response to the mildly stressful experimental procedure.

The in vivo effect of cocaine on NK cell activity may be due to its ability to stimulate the release of catecholamines into the bloodstream and to diminish the reuptake of norepinephrine by the sympathetic nervous system. Consistent with this hypothesis is the observation that the administration of subcutaneous epinephrine or the infusion of norepinephrine to humans increases NK cell activity (24-26). Also, after subcutaneous epinephrine in humans, there is an increase in lymphocytes bearing HNK-1, an antigen expressed by the majority of NK cells (24).

If cocaine increases NK cells and lytic activity through its sympathomimetic actions, then an increase in endogenous catecholamines may have effects on the immune system. In support of this, exercise increases plasma catecholamine levels and also increases NK cell activity $(22,23,36-38)$. After exercise the increase in activity appears to result both from an increase in circulating NK cells and from an increase in their lytic activity $(22,23)$.

Stimulation of NK cell activity may not have desirable biological consequences. While NK cells and/or related Leu-11+ cells may play a role in host defense, they also appear to impair the differentiation, proliferation, and activity of B cells, especially their ability to produce antibodies (10-18). Thus, the ability of cocaine to stimulate NK cell activity may have adverse effects on immunity. Moreover, the pathological and disruptive consequences of cocaine abuse are well known. Therefore, we advise against the clinical use of cocaine to increase NK cell activity. Our protocol did not include sustained administration of cocaine to humans. We therefore do not know if repeated doses of cocaine might lead to tolerance with regard to effects on NK cell activity.

Cocaine-induced changes in natural killing support a role for the sympathetic nervous system in the regulation of these cytotoxic cells. This allows insight into one mechanism by which the nervous system may alter lymphocyte activity.

\section{Acknowledgments}

We thank Rita Emelia and Denise Go for preparing the manuscript.

This work was supported by Veterans Administration and by U. S. Public Health Service grants GM30544, DA00053, DA00065, DA02829, and CA34529.

\section{References}

1. Herberman, R. B., M. E. Nunn, H. T. Holden, and D. H. Lavrin. 1975. Natural cytotoxic reactivity of mouse lymphoid cells against syngeneic and allogeneic tumors. II. Characterization of effector cells. Int. J. Cancer. 16:230-239.

2. Gorelik, E., M. Fogel, M. Feldman, and S. Segal. 1979. Difference in resistance of metastatic cells from local tumor growth to cytotoxicity of natural killer cells. J. Natl. Cancer Inst. 63:1397-1404.

3. Tolmadge, J. E., K. M. Meyers, D. J. Prieur, and J. R. Starkey. 1980. Role of NK cells in tumor growth and metastasis in beige mice. Nature (Lond.). 284:623-624.

4. Riccardi, C., A. Santoni, T. Barlozzari, P. Puccetti, and R. B. Herberman. 1980. In vivo natural reactivity of mice against tumor cells. Int. J. Cancer. 25:475-486.

5. Hanna, N., and I. J. Fedler. 1980. Role of natural killer cells in the destruction of circulating tumor emboli. J. Natl. Cancer Inst. 65: 801-809.

6. Warner, J. F., and G. Dennert. 1982. Effects of a cloned cell line with $\mathrm{NK}$ activity on bone marrow transplants, tumor development and metastasis in vivo. Nature (Lond.). 300:31-34.

7. Sheil, J. M., P. H. Gallimore, S. G. Zimmer, and M. L. Sopori. 1984. Susceptibility of adenovirus 2-transformed rat cell lines to natural killer (NK) cells: Direct correlation between NK resistance and in vivo tumorigenesis. J. Immunol. 132:1578-1582.

8. Ching, C., and C. Lopez. 1979. Natural killing of herpes simplex virus type 1-infected target cells: Normal human responses and influence of antiviral antibody. Infect. Immun. 26:49-56.

9. Bishop, G. A., J. C. Glorioso, and S. A. Schwartz. 1983. Relationship between expression of herpes simplex virus glycoproteins and susceptibility of target cells to human natural killer activity. J. Exp. Med. 157:1544-1561.

10. Duwe, A. K., and S. K. Singhal. 1979. The immunoregulatory role of bone marrow. II. Characterization of a suppressor cell inhibiting the in vitro antibody response. Circular Immunol. 43:372-381.

11. Herberman, R. B. 1982. Immunoregulation by natural killer cells. Molecular Immunol. 19:1313-1321.

12. Nabel, G., W. J. Allard, and H. Cantor. 1982. A cloned cell line mediating natural killer cell function inhibits immunoglobulin secretion. J. Exp. Med. 156:658-663. 
13. Tilden, A. B., T. Abo, and C. M. Balch. 1983. Suppressor cell function of human granular lymphocytes identified by HNK-1 (LEU7) monoclonal antibody. J. Immunol. 130:1171-1175.

14. Abruzzo, L. V., and D. A. Rowley. 1983. Homeostasis of the antibody response: Immunoregulation by NK cells. Science (Wash. DC). 222:581-585.

15. Arai, S., H. Yamamoto, K. Itohand, and K. Kumagai. 1983. Suppressive effect of human natural killer cell on pokeweed mitogeninduced B cell differentiation. J. Immunol. 131:651-657.

16. Horwitz, D. A., and A. C. Bakke. 1984. An Fc receptor-bearing, third population of human mononuclear cells with cytotoxic and regulatory function. Immunol. Today. 5:148-153.

17. Brieva, J. A., S. Targan, and R. H. Stevens. 1984. NK and T cell subsets regulate antibody production by human in vivo antigen-induced lymphoblastoid B cells. J. Immunol. 132:611-615.

18. Targan, S., J. Brieva, W. Newman, and R. Stevens. 1985. Is the NK lytic process involved in the mechanism of NK suppression of antibody-producing cells? J. Immunol. 134:666-669.

19. Masucci, M. G., R. Szigeti, E. Klein, G. Klein, J. Gruest, L. Montagnier, H. Taira, A. Hall, S. Nagata, and C. Weissmann. 1980. Effect of interferon-1 from E. coli on some cell functions. Science (Wash. DC). 209:1431-1435.

20. Ortaldo, J. R., R. B. Herberman, C. Harvey, P. Osheroff, Y. C. E. Pan, B. Kelder, and S. Pestka. 1984. A species of human $a$ interferon that lacks the ability to boost human natural killer activity. Proc. Natl. Acad. Sci. USA. 81:4926-4929.

21. Svedersky, L. P., H. M. Shepard, S. A. Spencer, M. R. Shalaby, and M. A. Palladino. 1984. Augmentation of human natural cell-mediated cytotoxicity recombinant human interleukin 2 . J. Immunol. 133: 714-718.

22. Edwards, A. J., T. H. Bacon, C. A. Elms, R. Verdi, M. Felder, and S. C. Knight. 1984. Changes in the populations of lymphoid cells in human peripheral blood following physical exercise. Clin. Exp. Immunol. 58:420-427.

23. Targan, S., L. Britvan, and F. Dorey. 1981. Activation of human NKCC by moderate exercise: increased frequency of NK cells with enhanced capability of effector-target lytic interactions. Clin. Exp. Immunol. 45:352-360.

24. Crary, B., S. L. Hauser, M. Borysenko, I. Kutz, C. Hoban, K. A Ault, H. L. Weiner, and H. Benson. 1983. Epinephrine-induced changes in the distribution of lymphocyte subsets in peripheral blood of humans. J. Immunol. 131:1178-1181.
25. Tonnesen, E., J. Tonnesen, and N. J. Christensen. 1984. Augmentation of cytotoxicity by natural killer (NK) cells after adrenaline administration in man. Acta Path. Microbiol. Immunol. Scand. 92:8183.

26. Kraus, L., S. Locke, I. Kutz, S. Edbril, K. Phillips, and H. Benson. 1983. Altered natural killer cell activity during norepinephrine infusion in humans. Annu. Meeting Am. Psychosomatic Soc., New York.

27. Katz, P., A. M. Zaytoun, and A. S. Fauci. 1982. Mechanisms of human cell-mediated cytotoxicity. J. Immunol. 129:287-296.

28. Chiueh, C. C., and I. J. Kopin. 1978. Centrally mediated release by cocaine of endogenous epinephrine and norepinephrine from the sympathoadrenal medullary system of unanesthetized rats. J. Pharmacol. Exp. Ther. 205:148-154.

29. Rowbotham, M. C., R. T. Jones, N. L. Benowitz and P. Jacob. 1984. Trazodone-oral cocaine interactions. Arch. Gen. Psychiatry. 41: 895-899.

30. Jacob, P., B. A. Elias-Baker, R. T. Jones, and N. L. Benowitz. 1984. Determination of cocaine in plasma by automated gas chromatography. J. Chromatography. 306:173-181.

31. Seaman, W. E., T. D. Gindhart, M. A. Blackman, B. Dalal, N. Talal, and Z. Werb. 1982. Suppression of natural killing in vitro by monocytes and polymorphonuclear leukocytes. J. Clin. Invest. 69:876888.

32. Herberman, R. B., S. Bartram, J. S. Haskill, M. Nunn, H. T. Holden, and W. H. West. 1977. Fc receptors on mouse effector cells mediating natural cytotoxicity against tumor cells. J. Immunol. 119: 322-326.

33. Edwards, A. L. 1967. Statistical Methods. Holt, Rinehart and Winston, Inc., New York. 293-322.

34. Welch, W. D. 1983. Effect of cocaine on non-specific human cellular host defenses. Res. Commun. Subst. Abuse. 4:1-9.

35. Takagi, S., S. Kitagawa, K. Oshimi, F. Takaku, and Y. Miura. 1983. Effect of local anaesthetics on human natural killer cell activity. Clin. Exp. Immunol. 53:477-481.

36. Banister, E. W., and J. Griffiths. 1972. Blood levels of adrenergic amines during exercise. J. Appl. Physiol. 33:674-676.

37. Brodde, O. E., A. Daul, and N. O'Hara. 1984. B-adrenoceptor changes in human lymphocytes, induced by dynamic exercise. Arch. Pharmacol. 325:190-192.

38. Butler, J., M. O'Brien, K. O’Malley, and J. G. Kelly. 1982. Relationship of B-adrenoreceptor density to fitness in athletes. Nature (Lond.). 298:60-62. 